\title{
Evaluation of the Quality of Commercial Fish Feeds in India with Respect to Microbiological Parameters
}

\author{
Sanal Ebeneezar ${ }^{1 *}$, T.V. Sankar ${ }^{3}$, Pankaj Kishore ${ }^{3}$, S.K. Panda ${ }^{3}$, D. Linga Prabu ${ }^{1}$, \\ S. Chandrasekar ${ }^{2}$, Livi Wilson ${ }^{1}$ and P. Vijayagopal ${ }^{1}$ \\ ${ }^{1}$ ICAR-Central Marine Fisheries Research Institute, Ernakulam North PO, Kochi, India \\ ${ }^{2}$ ICAR-Central Marine Fisheries Research Institute, Mandapam Camp, Tamilnadu, India \\ ${ }^{3}$ ICAR-Central Institute of Fisheries Technology, Kochi, India
}

*Corresponding author

\section{A B S T R A C T}

This paper describes the first comprehensive study of the quality of commercial fish feeds in India with regard to microbiological indices. Quality of feed is an important parameter

\section{Keywords}

Microbiological quality, Fish feeds, pathogens, Feed quality and safety

Article Info

Accepted:

15 January 2018

Available Online:

10 February 2018 that has a direct impact on the outcome of any aquaculture system. Microbiological parameters such as total plate count (TPC), Escherichia coli $\left(\mathrm{CFUg}^{-1}\right)$, coliformes $\left(\mathrm{CFUg}^{-1}\right)$, Enterobacteriaceae $\left(\mathrm{CFUg}^{-1}\right)$ and yeast and mould $\left(\mathrm{CFUg}^{-1}\right)$ counts were analysed using $3 \mathrm{M}^{\mathrm{TM}}$ Petrifilm ${ }^{\mathrm{TM}}$ as per guidelines. The TPC ranged from $2.0 \times 10^{2}$ to 3.13 $\times 10^{4} \mathrm{CFUg}^{-1}$ in different feeds. Presence of $E$. coli was detected in one of the feeds with $1.15 \times 10^{2} \mathrm{CFUg}^{-1}$. Coliform bacteria were not detected in any of the feeds. Enterobacteriaceae was present in three feeds in the range of $5.45 \times 10^{2}$ to $1.58 \times 10^{3}$ $\mathrm{CFUg}^{-1}$. Yeast and mould count ranged from $<10$ to $1.68 \times 10^{4} \mathrm{CFUg}^{-1}$ in the feeds analyzed. The results obtained from the present study indicate that the feeds were contaminated with micro-organisms. As far as Indian scenario is concerned, there exist several feed companies which do not comply with the quality regulations and specifications as laid down by the Bureau of Indian Standards (BIS). In addition, specifications are not available for aqua feeds regarding the acceptable levels of microbiological parameters. Hence the present study calls for a standardized code of quality to be observed by feed manufacturing companies for quality products.

\section{Introduction}

Formulated feed plays a significant role in semi intensive fish farming where a high stocking density of fish is maintained than the natural fertility of the water can support (Jhingran, 1991). The use of commercial feeds with well-balanced nutritional profile has become crucial for the success of aquaculture under intensive conditions (Abid and Ahmed, 2009). Formulated feed is found to be useful in providing adequate nutrient components and energy required for better fish growth and production and is known to increase the carrying capacity of culture system thereby enhancing fish production by several folds (Nazish and Mateen, 2011). The net fish production obtained when fed with 
supplementary feed was 7.7 times greater as compared to the treatment without feed in polyculture system (Kabir et al., 2009). There is a growing interest among the farmers to opt for pelleted feed over traditional feeds such as mash for fish culture which are comparatively superior to mash feed since, loss of nutrients out of leaching and wastage of feed is less. Moreover, as the feed wastage is less, physico-chemical and biological conditions of the aquaculture system under application of pellet feed might be better because of less decomposition and organic loading. Feed comprises about $60 \%$ of the total cost of any aquaculture venture. The global demand for formulated feeds for fish was estimated to be 29.3 million tonnes in 2008 and is expected to grow with increasing aquaculture (FAO, 2011).

Microbiological parameters are important to determine the safety and quality of feeds. Feed may be contaminated during processing, storage, transport or handling. Contaminated feed frequently causes disease and for that reason, it is necessary to establish surveillance programs for microbiological feed hazards (Radanov et al., 1999). Feed ingredients must be safe and suitable for storage and consumption. Even a single unsafe component may jeopardize the quality of compound feed. Some microorganisms introduced during storage, primarily moulds, can negatively affect feed quality including reducing dry matter and nutrients, causing musty or sour odours, and producing toxins (Meeusen, 1997).

The microbiological indices of feed quality include Total plate count (TPC), Escherichia coli count, coliforms, Enterobacteriaceae count, yeast and mould count etc. Therefore, in the present study the microbiological quality of commercial fish feeds was analysed to understand the quality of fish feed available in the country.

\section{Materials and Methods}

\section{Feed collection and sample preparation}

Eight different brands of commercial fish feeds were selected for the experiment. The feeds were procured from the retail markets of Kochi, India. Triplicate samples of the eight feeds were aseptically transferred to the microbiology laboratory where the analyses were carried out.

$25 \mathrm{~g}$ of each powdered feed was added to $250 \mathrm{~mL}$ of phosphate buffer in a plastic pouch and blended in a stomacher to form a homogenous mix. Aliquots of different dilutions $\left(10^{-1}, 10^{-2}, 10^{-3}, 10^{-4}\right.$ and $\left.10^{-5}\right)$ were prepared using phosphate buffer.

\section{The $3 \mathrm{M}^{\mathrm{TM}}$ Petrifilm aerobic count plates}

The $3 \mathrm{M}^{\mathrm{TM}}$ Petrifilm plate is an all-in-one plating system manufactured and patented by the Food Safety Division of the 3M Corporation. They are widely used in many microbiology related fields and are an efficient method for detection and enumeration of microorganisms compared to conventional plating techniques. The $3 \mathrm{M}$ petrifilms are specifically available for estimation of various parameters including Total plate count, $E$. coli, coliformes, Enterobacteriaceae, yeast and mould etc. (Fig. 1).

In order to inoculate, the top layer of petrifilm was lifted to expose the plating surface, and with a pipette, one $\mathrm{mL}$ of each dilution was transferred to the plating surface.

The top film was then slowly rolled down and a 'spreader' was used for even distribution. After inoculation, the petrifilms were kept in incubator for a specified period of time for each test. After incubation, the colonies formed in films were counted using a colony counter. 


\section{Microbiological parameters}

The commonly acceptable microbiological techniques such as Total Plate count (TPC), Escherichia coli count, Coliforms count, Enterobacteriaceae count and yeast and mould count were performed in the present study to describe the microbiological quality of commercial aqua feeds.

\section{Results and Discussion}

The results of microbiological evaluation of commercial fish feeds are summarized in Table 1. Microbiological evaluation of fish feeds gives qualitative as well as quantitative indication of the microbial load associated with them. The microorganisms detected in the feeds may be due to defective processing conditions of the feed and/or due to improper storage conditions. E. coli is implicated in disease conditions such as colibacillosis which occurs in forms such as enteric and septicaemic colibacillosis whereas Salmonella sp., Listeriasp. and Staphylococcus aureus are capable of producing acute and chronic infections in all or most types of birds and animals (Mallinson, 1984).

Ogbulie (1998) reported that bacterial genera may have originated from nitrogenous waste products in compounding animal feeds such as dung, chicken excreta etc., and fungal species may have resulted from carry-over of over seasoned fungal species from the field.

Handling and other post-harvest process may also contribute as the primary sources of contamination. Most of the fungal species have been isolated from cereals (Pitt et al., 1994).

\section{Total Plate Count}

The TPC is one of the most common tests applied to indicate the sanitary quality, organoleptic acceptability, adherence to good manufacturing practices, and to a lesser extent, as an indicator of safety of food/ feed. It is also known as aerobic colony count, standard plate count, mesophilic count or total viable count. It gives an indication of the bacterial populations in a sample. The TPC defines how many aerobic, mesophilic microorganism colonies, such as bacteria, yeast, and mould fungi will grow for $72 \mathrm{~h}$ on an agar plate that was normalized for microbiological testing at $30^{\circ} \mathrm{C}$. In this study, the TPC ranged from $2.0 \mathrm{x}$ $10^{2}$ to $3.13 \times 10^{4} \mathrm{CFU} \mathrm{g}{ }^{-1}$ in different feeds.

\section{Escherichia coli count}

The presence of $E$. coli in feeds is undesirable because it indicates poor hygienic conditions which have led to contamination or inadequate heat treatment. Ideally $E$. coli should not be detected and as such a level of $<3$ per gram (the limit of the Most Probable Number test) has been given as the satisfactory criteria for this organism. Levels exceeding 100 per gram are unacceptable and indicate a level of contamination which may have introduced pathogens or that pathogens, if present in the food prior to processing, may have survived (ICMSF, 1996). In the present study, the level of $E$. coli was within the acceptable limits except in feed D with $1.15 \times 10^{2} \mathrm{CFU} \mathrm{g}^{-1}$.

\section{Coliforms count}

Coliform bacteria are a commonly used bacterial indicator of sanitary quality of foods and water. Coliforms can be found in the aquatic environment, in soil and on vegetation; they are universally present in large numbers in the feces of warm-blooded animals. They are easy to culture, and their presence is used to indicate that other pathogenic organisms of fecal origin may be present (ICMSF, 1996). Coliform bacteria were within satisfactory limits in the commercial fish feeds analyzed in this study. 
Table.1 Microbiological evaluation of commercial fish feeds

\begin{tabular}{|c|c|c|c|c|c|c|c|c|}
\hline \multirow[b]{2}{*}{ PARAMETERS } & \multicolumn{8}{|c|}{ FEEDS } \\
\hline & A & B & $\mathrm{C}$ & $\mathrm{D}$ & $\mathrm{E}$ & $\mathrm{F}$ & $\mathrm{G}$ & $\mathrm{H}$ \\
\hline TPC $\left(\right.$ CFU g g $\left.^{-1}\right)$ & $\begin{array}{l}5.5 x \\
10^{2}\end{array}$ & $\begin{array}{l}3.50 \\
\times 10^{2}\end{array}$ & $1.66 \times 10^{4}$ & $1.65 \times 10^{4}$ & $3.13 \times 10^{4}$ & $\begin{array}{l}2.0 \times \\
10^{2}\end{array}$ & $\begin{array}{l}6.00 \\
\times 10^{2}\end{array}$ & $\begin{array}{l}1.76 \\
\times 10^{4}\end{array}$ \\
\hline E.coli $(\text { CFU g g })^{-1}$ & $<10$ & $<10$ & $<10$ & $1.15 \times 10^{2}$ & $<10$ & $<10$ & $<10$ & $<10$ \\
\hline Coliformes (CFU g $\left.{ }^{-1}\right)$ & $<10$ & $<10$ & $<10$ & $<10$ & $<10$ & $<10$ & $<10$ & $<10$ \\
\hline $\begin{array}{l}\text { Enterobacteriaceae } \\
\left.\text { (CFU g }{ }^{-1}\right)\end{array}$ & $<10$ & $\begin{array}{l}5.45 \times \\
10^{2}\end{array}$ & $1.58 \times 10^{3}$ & $1.58 \times 10^{3}$ & $<10$ & $<10$ & $<10$ & $<10$ \\
\hline $\begin{array}{l}\text { Yeast and mould } \\
\left(C F U \mathbf{g}^{-1}\right)\end{array}$ & $1.5 \times 10^{1}$ & $3.2 \times 10^{1}$ & $1.25 \times 10^{3}$ & $5.4 \times 10^{2}$ & $2.2 \times 10^{2}$ & $<10$ & $2 \times 10^{2}$ & $1.68 \times 10^{4}$ \\
\hline
\end{tabular}

Fig.1 Petrifilms specific for (A) TPC (B) Enterobacteriacea (C) Coliforms (D) Yeast and mould (E) E. coli

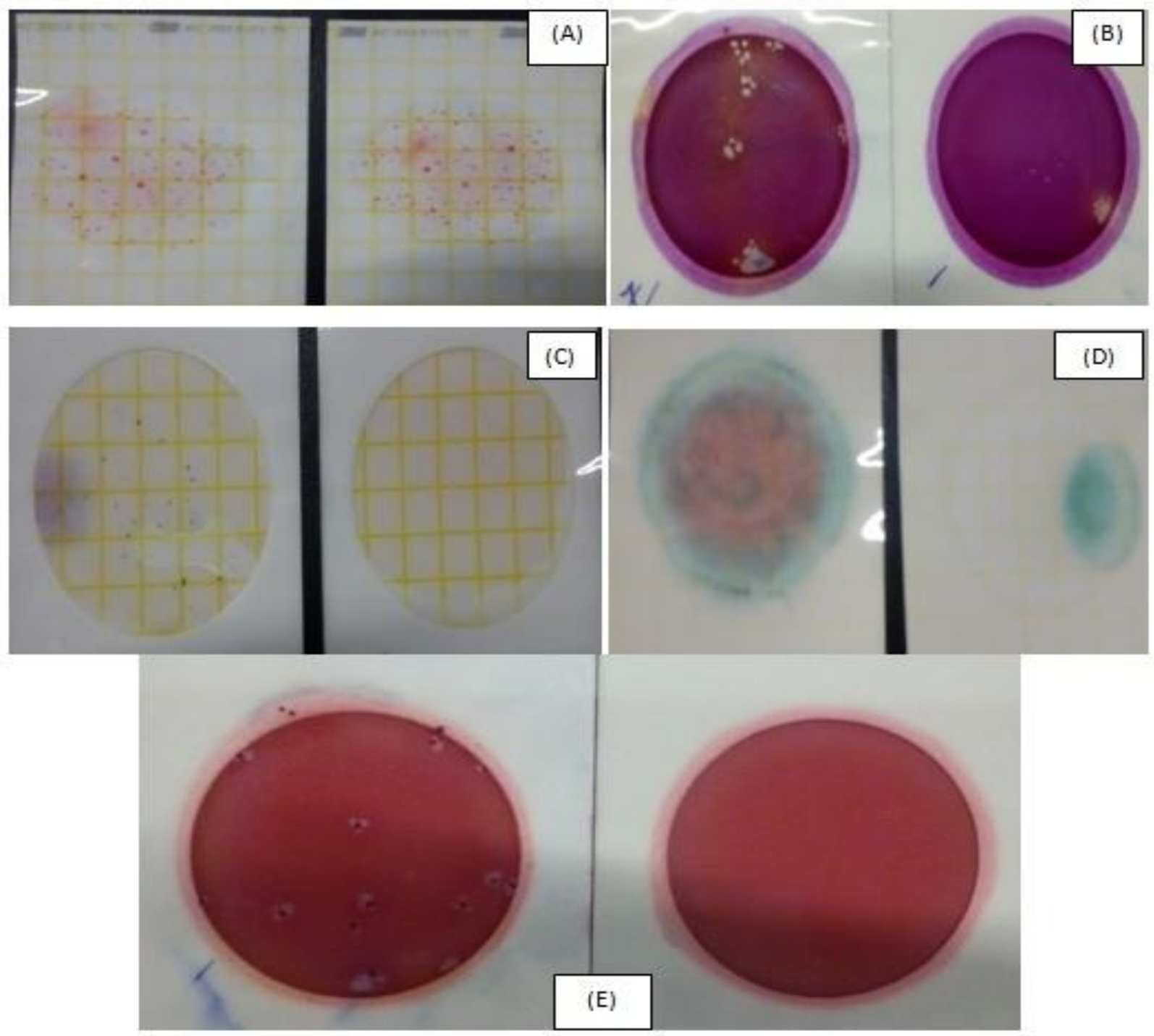




\section{Enterobacteriaceae count}

The family Enterobacteriaceae includes gram negative bacteria including harmless symbionts and human pathogens such as Salmonella sp. and Shigella sp. They are useful indicators of hygiene and of postprocessing contamination of heat processed foods/ feed. High numbers of Enterobacteriaceae (>104 per gram) in readyto-eat foods indicates an unacceptable level of contamination or inadequate processing conditions (FSANZ, 2001). (e.g. inadequate cooking). In feeds B, C and D, a higher load of Enterobacteriaceae was detected.

\section{Yeast and mould count}

Yeasts are eukaryotic microorganisms classified as members of the kingdom fungi. Some species of yeast are opportunistic pathogens that can cause infection. They are able to grow in feeds with low $\mathrm{pH}$ (5.0 or lower) and in the presence of sugars, organic acids, and other easily metabolized carbon sources. During their growth, yeasts metabolize some feed components and produce metabolic end products which causes spoilage due to alteration in physical, chemical, and sensible properties of feed. A mould is a fungus that grows in the form of multicellular filaments called hyphae. Some mould varieties present in feed produce mycotoxins that can pose health risks. Improper storage of feed without proper packaging and under humid condition accelerate the growth of moulds. Except in feed F, yeast and mould colonies were detected in all other feeds. Exceptionally high concentration of yeast and mould colonies $\left(1.68 \times 10^{4} \mathrm{CFU} \mathrm{^{-1 }}\right)$ were detected in feed $\mathrm{H}$. Although it is not possible to produce microbe-free feed without adversely affecting its nutritional value, hazards due to microbial action can be minimized to a significant extent through appropriate quality control measures in different stages of feed processing and storage.

Feed materials may serve as carriers for a wide variety of microorganisms. It is believed that lower number of microorganisms decreases the probability of pathogens occurrence (Bryan, 1982). The presence of microorganisms is unavoidable on account of the permanent contact of plant feed materials with soil and dust during the growing season and harvesting. However, the efforts to reduce the number of microorganisms in feed as much as possible show that the ultimate goal is not sterile feed but feed with "safe contamination level". In India, quality specification of feeds for most cultured fish (except for carps and cat fish) and ornamental fish is lacking. Specifications are important since they act as measuring sticks, which forms the foundation of a quality assurance programme because they provide accurate information to all the stakeholders involved in the chain of fish feed manufacture and utilization. In the present study, some of the fish feeds were not found to be satisfactory/ conforming to existing quality requirements as laid down by BIS. Even though the commercial feed manufacturers have followed most of the quality parameters; still further scope of improvement is possible. In BIS specifications for fish feeds, some more parameters of relevance such as the microbiological parameters, maximum allowable limit of pesticide residues and heavy metals should also be included for the production and supply of quality feeds.

\section{Acknowledgements}

The authors are grateful to the Director, ICAR-CIFT, Kochi and the Director, ICARCMFRI, Kochi for the successful completion of this research work. We also wish to thank the Scientists and Technical officers of the Quality Assurance and Management Division, 
ICAR-CIFT, Kochi for the co-operation extended during the period of study.

\section{References}

A.O.A.C., 2000. Official Method 965.33 Peroxide Value in Oils and Fats / Pearsons Composition and Analysis of Foods 9th edn p 641.

Abid, M and Ahmed, S. M., 2009.Growth response of Labeo rohita fingerlings fed with different feeding regimes under intensive rearing. J. Anim. Plant Sci., 19 (1), pp 45-49.

Bryan, F.L., 1982. Diseases transmitted by foods. Centers for Disease Control and Prevention, U. S. Department of health and human services. Atlanta, pp 1-95.

FAO, 2011. Aquaculture development. Use of wild fish as feed in aquaculture. FAO Technical Guidelines for Responsible Fisheries. No. 5, Suppl. 5. FAO, Rome, p. 79.

Food Standards Australia New Zealand (FSANZ) 2001. Guidelines for the microbiological examination of readyto-eat foods. (https://www.foodstandards.gov.au/cod e/microbiollimits/documents/Guidelines $\% 20$ for\%20Micro\%20exam.pdf).

International Commission on Microbiological Specification for Food (ICMSF), 1996. Sampling for Microbiological Analysis. Principles and Specific Applied, University of Toronto, pp: 1-18.

Jhingran, V.G., and Pullin, R.S.V., 1985. A hatchery manual for the Common, Chinese and Indian major carps. Asian Development Bank, International
Centre for Living Aquatic Resources management. $191 \mathrm{pp}$.

Kabir, A.N., Hossain M.A. and Rahman, M.S., 2009. Use of duckweed as feed for fishes in polyculture. J. Agric. Rural. Dev. 7: 157-160.

Mallinson, E. T., 1984. Infectious diseases. In: Animal Health. Jack Hayes (ed). Bureau of Animal Industry (Publisher), Maryland, U.S.A.

Meeusen, A., 1997. Treatment of grains to prevent mold and mycotoxins during storage of raw materials. VII Technology Symposium on Improving food and animal fodder technology, Tara. Proceedings, 113-118.

Nazish, N. and A. Mateen., 2011. Winter growth of carps under different semiintensive culture conditions. Paistank. Vet. J., 31 (2): 134-136 pp.

Ogbulie, J.N and Okpokwasili G.C., 1998. Efficacy of chemotherapeutic agents in controlling bacterial diseases of cultured fish. Journal of Aquaculture in the Tropics. 13: $61-72$.

Pitt, J. I., Hocking A. D., Kanjana, B., Miseamble, B. F., Wheeler, K. A. and Tanboon P., 1994. The normal mycoflora of commodities form Thailand Rice, Beans and other commodities. International Journal of Environmental Health Research. 4: 102 $-108$.

Radanov-pelagic V., Juric V., Kunc V., Ristic M. and Koljajic V., 1999. The relationship of microflora and quantity of mycotoxins in animal feed. Faculty of Agriculture, Novi Sad 48, 281-284.

\section{How to cite this article:}

Sanal Ebeneezar, T.V. Sankar, Pankaj Kishore, S.K. Panda, D. Linga Prabu, S. Chandrasekar, Livi Wilson and Vijayagopal, P. 2018. Evaluation of the Quality of Commercial Fish Feeds in India with Respect to Microbiological Parameters. Int.J.Curr.Microbiol.App.Sci. 7(02): 14781483. doi: https://doi.org/10.20546/ijcmas.2018.702.179 